\title{
Cross-cultural adaptation of the SCATBI instrument for cognitive-linguistic abilities after traumatic brain injury
}

\author{
Adaptação transcultural do instrumento SCATBI para avaliação cognitiva após \\ traumatismo cranioencefálico
}

Ester Priscila Janzen1', Roger Walz 2,3, Katia Lin²,3

\begin{abstract}
Objective: To perform the cross-cultural adaptation of the "Scales of Cognitive Ability for Traumatic Brain Injury" (SCATBI). Method: After the translation and back-translation phases, a multidisciplinary committee judged and elaborated versions in order to maintain its conceptual equivalence, content, comprehensibility and contextual adjustment for Brazilian population. The final version was tested on 55 healthy subjects. Results: The individuals' mean age was $41.75 \pm 17.40$ years (range = 18-81), 69\% were women and they had a mean schooling of $12.96 \pm 4.55$ years. Higher total scores were positively correlated with years of schooling $(p<0.001)$ and social-economic status $(p=0.001)$, while older aged individuals performed worse than younger ones $(p=0.001)$. Both genders performed similarly on all domains of the instrument, except for "organization" ability, where women performed significantly better than men ( $p=0.02$ ). Conclusion: The Brazilian version of SCATBI is a useful tool for the diagnosis and monitoring of cognitive impairments after a traumatic brain injury.
\end{abstract}

Keywords: craniocerebral trauma, SCATBI, cognition, language, rehabilitation.

\section{RESUMO}

Objetivo: Realizar a adaptação transcultural do questionário "Scales of Cognitive Ability for Traumatic Brain Injury" (SCATBI) para avaliação das habilidades linguístico-cognitivas após traumatismo cranioencefálico (TCE). Método: Após as fases de tradução e retrotradução do instrumento, uma equipe multidisciplinar julgou as versões obtidas quanto à manutenção do conceito original, compreensibilidade e clareza para a população brasileira. A versão final foi testada em 55 indivíduos saudáveis. Resultados: Os indivíduos possuíam média de idade de 41,75 anos (18-81), escolaridade de 12,96 anos, e 69\% eram mulheres. Escores mais altos no SCATBI foram positivamente correlacionados com a escolaridade $(p<0,001)$ e status sócio-econômico ( $p=0,001)$, enquanto indivíduos mais velhos tiveram pior desempenho $(p=0,001)$. Na comparação dos gêneros houve diferença estatisticamente significativa apenas no domínio Organização ( $p=0,02$ ). Conclusão: Por ser uma bateria cognitiva abrangente, que avalia indivíduos em extensa faixa de idade, a versão brasileira do SCATBI é um instrumento sensível para diagnóstico e acompanhamento das alterações cognitivas comumente prejudicadas após um TCE.

Palavras-chave: traumatismo craniocerebral, SCATBI, cognição, linguagem, reabilitação.

Traumatic brain injury (TBI), according to the World Health Organization (WHO), is an important public health problem due to its high rates of incidence, morbidity and mortality ${ }^{1,2}$ in many countries including Brazil. It is a major cause of incapacity, with most of the burden occurring in low-income and middle-income countries ${ }^{3,4,5,6}$.

The resulting cascade of pathological changes disrupts neural functioning at multiple levels, from individual

1 Universidade Federal de Santa Catarina, Hospital Universitário, Programa de Pós-Graduação em Ciências Médicas, Florianópolis SC, Brazil; ${ }^{2}$ Universidade Federal de Santa Catarina, Hospital Universitário, Centro de Neurociências Aplicadas, Florianópolis SC, Brazil;

${ }^{3}$ Universidade Federal de Santa Catarina, Hospital Universitário, Serviço de Neurologia, Departamento de Clínica Médica, Florianópolis SC, Brazil. Correspondence: Katia Lin; Departamento de Clínica Médica, Hospital Universitário Polydoro Ernani de São Thiago; Rua Prof. Maria Flora Pausewang s/n / 3ªndar; Caixa Postal: 5199, Campus Universitário; 88040-900 Florianópolis SC, Brasil; E-mail: linkatia@uol.com.br

Conflict of interest: There is no conflict of interest to declare.

Support: NENASC Project (Núcleo de Excelência em Neurociências Aplicadas) of Programa de Apoio a Núcleos de Excelência (PRONEX-FAPESC/CNPq) and CAPES (Coordination of Improvement of Higher Education Personnel) for their financial support. The authors, KL and RW, hold a CNPq (Brazilian Council for Scientific and Technologic Development, Brazil) Research Fellowship and EPJ receives Research Scholarship from CAPES.

Received 10 February 2015; Received in final form 09 June 2015; Accepted 30 June 2015. 
celular and vascular structures to larger brain networks ${ }^{7}$. This rapid deformation of brain anatomy and physiology results in clinical neurological and neurobehavioral impairments ultimately affecting an individual's cognition, vegetative and emotional functions, as well as social behavior abilities $3,5,6,7,8$.

The TBI may result in multiple cognitive deficits. The most commonly found sequelae are deficits in attention and memory, difficulty in learning new information, resolving problems, planning; as well as disturbances associated with impulsivity, self-control ${ }^{9,10}$ and personality changes ${ }^{3,5,6}$.

Currently, a limited number of test batteries has been developed to assess the presence and severity of cognitive-communicative deficits associated with TBI. In fact, before 1990s, clinicians used tests developed for other patient populations (particularly tests for aphasia) or resorted to their own informal and not validated protocols ${ }^{11,12}$.

The Scales of Cognitive Ability for Traumatic Brain Injury (SCATBI), developed by Adamovich and Henderson in 1992, provide a systematic method for assessing cognitive-linguistic deficits after TBI and they were designed to reveal quantitatively the extent of changes during and following cognitive rehabilitation. This test battery measures performance on five domains: Perception and Discrimination, Orientation, Organization, Recall and Reasoning. Each scale is made up of a series of small tests, or testlets that are summarized in Chart $1^{13}$.

Our study aimed to translate and to perform the cross-cultural adaptation of the SCATBI for Brazilian Portuguese. This study was also designed to describe the performance of a sample of healthy subjects submitted to the translated and adapted version for comparison and equivalence to the American version.

\section{METHODS}

\section{Study design and settings}

A signed document was obtained directly from the publisher and owner of all rights, who granted his authorization for the process of cross-cultural adaptation of the SCATBI questionnaire to Brazilian Portuguese. This study was conducted in accordance with the Code of Ethics of the World Medical Association (Declaration of Helsinki) ${ }^{14}$ and was only started after approval by the Ethics Committees for Human Research of the Federal University of Santa Catarina (UFSC). Informed consent was obtained from all participants before their inclusion in this protocol.

In accordance with previously published guidelines ${ }^{15,16}$, the process of cross-cultural adaptation of the SCATBI included the following five steps: [1] translation; [2] back-translation; [3] review by an expert committee to ensure semantic, idiomatic, experiential and conceptual equivalence; [4] testing of the pre-final version; and [5] analysis of the scores.
Chart 1. Five Scales and Their Associated 41 Testlets 13.

I. Perception and Discrimination

\begin{tabular}{|c|}
\hline Sound recognition \\
\hline Shape recognition \\
\hline Word recognition (no distraction) \\
\hline Word recognition (with distraction) \\
\hline Color discrimination \\
\hline Shape discrimination \\
\hline Size discrimination \\
\hline Discrimination of color, shape, size \\
\hline Discrimination of pictured objects \\
\hline Auditory discrimination (real words) \\
\hline Auditory discrimination (nonsense) \\
\hline II. Orientation \\
\hline Premorbid questions \\
\hline Postmorbid questions \\
\hline III. Organization \\
\hline Identifying pictured categories \\
\hline Identifying pictured category members \\
\hline Word associations (word categories) \\
\hline Sequencing objects (size) \\
\hline Sequencing words (alphabetical) \\
\hline Sequencing events (time of year) \\
\hline Sequencing events (pictured task steps) \\
\hline Sequencing events (recall task steps) \\
\hline IV. Recall \\
\hline Memory for graphic elements \\
\hline Naming pictures (word retrieval) \\
\hline Immediate recall of word strings \\
\hline Delayed recall of word strings \\
\hline Cued recall of words \\
\hline Cued recall of words in discourse \\
\hline Word generation \\
\hline Immediate recall of oral directions \\
\hline Recall of oral paragraphs \\
\hline V. Reasoning \\
\hline Figural reasoning: matrix analogies \\
\hline Convergent thinking: central theme \\
\hline Deductive reasoning: elimination \\
\hline Inductive reasoning: opposites \\
\hline Inductive reasoning: analogies \\
\hline Divergent thinking: homographs \\
\hline Divergent thinking: idioms \\
\hline Divergent thinking: proverbs \\
\hline Divergent thinking: verbal absurdities \\
\hline Multiprocess reasoning: task insight \\
\hline Multiprocess reasoning: analysis \\
\hline
\end{tabular}

Multiprocess reasoning: analysis

Two native Brazilian bilingual individuals with perfect knowledge of English, who knew the purpose of this study, carried out the translation of the original instrument into Portuguese, thus creating two versions of SCATBI. These two versions were sent to two independent native English-speaking translators with full knowledge of both languages, who were residents in Brazil, not knowing the purpose of the study and who had no access to the original 
instrument, for back-translation. A multidisciplinary team made up the review committee. This group compared the translated versions with the original in English, analyzed the discrepancies between them, evaluated the clarity and comprehensibility of the questions, and assessed the cross-cultural equivalence with the source version of each item, in relation to the Brazilian population. Following this consensus meeting, a final version of the SCATBI-Portuguese instrument was obtained.

\section{The Instrument}

The SCATBI instrument is constituted by five scales (1 - Perception and discrimination; 2 - Orientation; 3 - Organization; 4 - Recall; and 5 - Reasoning) and each scale is made up of a series of small tests, or testlets, which are collections of similar items designed to measure a common trait or subdomain. In general, items within each testlet progress from easier to more difficult. The item scores are summed to produce a testlet score, and the testlet scores are summed to produce a total score for each of the five scales. The total raw score for each of the scales can be converted to normed scores (percentile ranks or standard scores). A severity score can be computed from the total composite score. The maximum possible score to be achieved throughout the questionnaire is 215 points. For each domain, the highest scores are as follows: Perception and Discrimination: 58 points; Orientation: 20 points; Organization: 30 points; Memory: 52 points; Reasoning: 55 points $^{13}$.

\section{Participants}

In order to assess the comprehensibility and average difficulty of this Brazilian Portuguese version of SCATBI and to estimate an upper bound of expectations for head-injured subjects, 55 healthy subjects were recruited to participate in the study. Exclusion criteria were: individuals younger than 18 years, and subjects with intellectual, psychiatric or emotional comorbidities that would prevent them from understanding and answering the questionnaire appropriately. Also, no subject had any neuropsychiatric disease nor family history.

All questionnaires were administered in face-to-face interviews. After the administration, the examiner asked: [1] Can you explain in your own words what you understood from that question? and [2] Were there any words in that question that you did not understand? If so, do you have any suggestion for making this question easier to understand?

\section{Statistical analysis}

Statistical analysis was performed using $\mathrm{IBM}^{\bullet} \mathrm{SPSS}^{\bullet}$ software package for Mac, standard version 21.0. Descriptive analysis was made to characterize the sample. Quantitative variables were expressed as mean \pm standard deviation (SD) and qualitative variables were expressed as percentage values. The following standard statistical tests were used for in-group and between-group comparison purposes wherever appropriate: chi-square test, Fisher's exact test, Student's t-test and Pearson's correlation. The internal consistency reliability of the SCATBI-Portuguese was assessed using Cronbach's alpha and Pearson's correlation. A p-value $<0.05$ was considered to be statistically significant.

\section{RESULTS}

The final Brazilian Portuguese version of SCATBI was completed in an average time of 90 minutes by each subject. The sociodemographic variables are listed in Table 1.

The patients' age ranged from 18 to 81 years. Fifty-four percent of the participants had a college degree, $32.7 \%$ graduated from high school, 3.6\% had only completed middle school (8 years of education). The percentage of individuals with a fourth grade schooling was $5.5 \%$ and with maximum of third grade, $3.6 \%$.

Table 2 demonstrates mean total and partial scores according to gender. There was a statistically significant difference only in the Organization ability score when comparing both genders, with $\mathrm{p}=0.02$. Both genders performed similarly on the other domains.

Table 1. Sociodemographic characteristics of participants.

\begin{tabular}{ll}
\hline Sociodemographic variables & $\mathrm{N}=55(\%)$ \\
\hline Gender & $17(30.9 \%)$ \\
Male & $38(69.1 \%)$ \\
Female & $41.7(17.4)$ \\
Age, mean (SD) & $12.9(4.6)$ \\
Years of schooling, mean (SD)
\end{tabular}

Table 2. Results of the t-test for equality of means for each domain of SCATBI-Portuguese instrument according to gender (student's t-test)

\begin{tabular}{lccccccc}
\hline & Gender & $\mathrm{N}$ & Min & Max & Mean & SD & $\mathrm{p}$ \\
\hline Total Score & Male & 17 & 178 & 213 & 201.59 & 8.797 & 0.183 \\
& Fem & 38 & 152 & 214 & 196.89 & 13.055 & \\
Perception and & Male & 17 & 56 & 58 & 57.65 & 0.606 & 0.087 \\
Discrimination & Fem & 38 & 53 & 58 & 57.03 & 1.404 & \\
Orientation & Male & 17 & 18 & 20 & 19.88 & 0.485 & 0.805 \\
& Fem & 38 & 16 & 20 & 19.73 & 1.917 & \\
Organization & Male & 17 & 29 & 30 & 29.88 & 0.332 & $0.021 *$ \\
& Fem & 38 & 20 & 30 & 28.87 & 2.559 & \\
Memory/Recall & Male & 17 & 36 & 51 & 45.29 & 4.607 & 0.246 \\
& Fem & 38 & 25 & 51 & 43.50 & 5.496 & \\
Reasoning & Male & 17 & 36 & 54 & 48.88 & 4.675 & 0.392 \\
& Fem & 38 & 27 & 55 & 47.50 & 5.811 & \\
Age & Male & 17 & 21 & 71 & 37.00 & 17.114 & 0.178 \\
& Fem & 38 & 18 & 81 & 43.87 & 17.322 & \\
\hline SD:standard deviation. & & & & & &
\end{tabular}


There was a statistically significant correlation between age and schooling in years versus total and partial scores in SCATBI:

1) AGE and TOTAL SCORE $(r=-0.434 ; \mathrm{p}=0.001)$, PERCEPTION $(r=-0.393$; $<<0.0001)$ and RECALL $(r=-0.390$; $\mathrm{p}<0.001)$. Pearson's $\mathrm{r}$ was negative for all these three correlations, meaning that the higher the age, the lower the score in the TOTAL SCORE, PERCEPTION and RECALL domains.

2) SCHOOLING IN COMPLETED YEARS and TOTAL SCORE $(r=0.719 ; \mathrm{p}<0.001)$, PERCEPTION $(r=0.450$; $\mathrm{p}=0.001)$, ORGANIZATION $(r=0.566$; $\mathrm{p}<0.001)$ and RECALL $(r=0.544 ; \mathrm{p}<0.001)$. The correlation was positive for all of them, meaning that the higher the schooling, the higher the score in TOTAL SCORE, PERCEPTION, RECALL and ORGANIZATION.

Regarding socioeconomic status (Table 3), individuals were grouped into two major groups ${ }^{17}$ : Classes A and B (group of 34 patients) and classes $\mathrm{C}$ and D (group of 21 patients). When comparing the mean total and partial scores for each group, there were statistically significant differences

Table 3. Socioeconomic levels and total and partial scores on SCATBI-Portuguese.

\begin{tabular}{lccccc}
\hline & $\begin{array}{c}\text { Socioeconomic } \\
\text { level }^{\mathrm{a}}\end{array}$ & $\mathrm{N}$ & Mean & SD & $\mathrm{p}^{\mathrm{b}}$ \\
\hline Total Score & $\mathrm{AB}$ & 34 & 202.91 & 7.633 & \\
Perception and & $\mathrm{CD}$ & 21 & 190.95 & 14.183 & $0.001^{*}$ \\
Discrimination & $\mathrm{AB}$ & 34 & 57.41 & 0.892 & \\
Orientation & $\mathrm{CD}$ & 21 & 56.90 & 1.640 & 0.204 \\
& $\mathrm{AB}$ & 34 & 19.88 & 0.478 & \\
Organization & $\mathrm{CD}$ & 21 & 20.10 & 2.567 & 0.638 \\
Memory/Recall & $\mathrm{AB}$ & 34 & 29.97 & 0.171 & \\
& $\mathrm{CD}$ & 21 & 27.90 & 3.161 & $0.007 *$ \\
Reasoning & $\mathrm{AB}$ & 34 & 45.82 & 4.596 & \\
& $\mathrm{CD}$ & 21 & 41.19 & 5.095 & $0.001 *$ \\
Schooling & $\mathrm{AB}$ & 34 & 49.82 & 3.520 & \\
& $\mathrm{CD}$ & 21 & 44.86 & 6.680 & $0.004^{*}$ \\
Age & $\mathrm{AB}$ & 34 & 14.91 & 2.948 & \\
& $\mathrm{CD}$ & 21 & 9.81 & 4.976 & $<0.001 *$ \\
& $\mathrm{AB}$ & 34 & 38.38 & 15.884 & \\
\hline
\end{tabular}

a Social stratification according to the classification of ABEP - Associação Brasileira de Empresas de Pesquisa - 2012 ${ }^{16}$; b Student's t-test; * Statistically significant with $p<0.05 ;$ SD: standard deviation.

Table 4. Pearson's correlation between each domain of the SCATBI-Portuguese and total score $(N=55)$.

\begin{tabular}{lcc}
\hline \multirow{2}{*}{ Domains } & \multicolumn{2}{c}{$\begin{array}{c}\text { Correlation with } \\
\text { SCATBI-Portuguese total score }\end{array}$} \\
\cline { 2 - 3 } & $\mathrm{r}$ & $\mathrm{p}$ \\
\hline Perception and Discrimination & 0.689 & $<0.0001^{*}$ \\
Orientation & 0.261 & 0.054 \\
Organization & 0.569 & $<0.0001^{*}$ \\
Memory/Recall & 0.873 & $<0.0001^{*}$ \\
Reasoning & 0.896 & $<0.0001^{*}$ \\
\hline * Statistically significant with $\mathrm{p}<0.05$. & &
\end{tabular}

in the total score $(\mathrm{p}=0.001)$ between higher $\mathrm{X}$ lower socioeconomic status; on account of organization $(p=0.007)$, recall $(p=0.001)$ and reasoning $(p=0.004)$, which were the partial scores that were higher among individuals with a higher socioeconomic level.

The Cronbach's alpha for internal consistency reliability of the SCATBI-Portuguese was 0.82 for all the five domains and total score $(\mathrm{N}=55)$. Pearson's correlations between each domain and total score are described in Table 4.

\section{DISCUSSION}

With the increase in the number of multinational and multicultural research projects, the need to adapt health status measures for use in other than the source language has also grown rapidly. Most questionnaires were developed in English-speaking countries. The cross-cultural adaptation of a questionnaire for use in a new country, culture, and/or language necessitates use of a unique method, to reach equivalence between the original source and target versions of the questionnaire. It is now recognized that if measures are to be used across cultures, the items must not only be translated well linguistically, but also must be adapted culturally to maintain the content validity of the instrument at a conceptual level across different cultures ${ }^{16,18,19,20}$.

The Brazilian Portuguese version of SCATBI was culturally adapted in a sample of 55 healthy subjects. The results indicated that the Portuguese version of the SCATBI battery only required minor modifications and was easily understood. No more than 90 minutes were required to complete it.

The SCATBI is a test designed to assess cognitive-linguistic status after TBI and to describe the extent of changes during and following rehabilitation. The original version was validated towards the Rancho Los Amigos Levels of Cognitive Functioning ${ }^{21}$ instrument as a measure of cognitive functioning. Its internal consistency reliability was assessed using Cronbach's alpha, reflecting high interitem consistency for the raw scores on the five scales (SCATBI-Original > 0.90; SCATBI-Portuguese $=0.82$ ) and classified $96 \%$ of the normal subjects as non-brain-injured and $79 \%$ of TBI subjects as brain-injured. These relatively high-levels of agreement with the previously made classifications positively support the predictive validity of the SCATBI ${ }^{13}$.

During the translation process, it was necessary to make some adjustments in order to be as close as possible to the content brought from the original scale. The translation team sought to favor the native language in order not to stray from the content presented by the scale in its original language. Questions, verbs, pronouns and verbal expressions were adjusted, to ensure that the connotative and denotative meanings were respected in the process of transferring the meaning of words between the two languages.

Some questions required complementary information for clarification as the following examples: 


\section{Example 1}

Question 9 - Recall

9. Use the Stimulus Tape. Play the tape of the first paragraph to the patient and then ask the questions below. Introduce the task by saying, "I want you to listen to a short story. Then I'll ask you some questions about it. Listen carefully so you can answer the questions." Score 1 point for each correct response. Score 0 for each incorrect response. Correct responses can be expanded without penalty; e.g., "dill pickles" for "a pickle" is a correct response.

A young man worked the night shift at the hospital, and every night his wife waited up for him. One night, he decided to treat his wife to a mid-night snack. He stopped at an all-night dinner and ordered a hot fudge sundae to go. As he waited for $i$, he saw a jar of dill pickles on the counter. When the proprietor came back with the ice cream, the young man ordered a pickle for himself. The proprietor put the sundae and the pickle in a box and said the total came to three dollars. The young man reached for his wallet, only to find he had left it at work. All he had was a dollar and fifty cents in change. The owner looked at the ice cream, then at the pickle, and smiled. He told the young man a dollar-fifty was enough.

After translation the values that were in dollars were changed for reais.

9. Use o CD de Estímulo. Reproduza a narração do parágrafo ao lado ao paciente e então faça as perguntas a seguir. Introduza a tarefa dizendo, "Quero que você escute uma pequena história. Então, farei algumas perguntas sobre ela. Ouça cuidadosamente para responder às perguntas". Registre um ponto para cada resposta correta. Registre zero para cada resposta incorreta. Respostas corretas podem ser expandidas sem penalidade: ex. "picles em conserva" para "picles" é uma resposta correta.

Um jovem trabalhava no turno da noite no hospital e toda noite sua mulher o esperava acordada. Certa noite, ele decidiu dar à sua mulher um lanche de 'meio da noite'. Ele parou em uma lanchonete aberta 24 h e pediu um sundae com cobertura para viagem. Enquanto aguardava, ele viu um vidro de picles em conserva no balcão. Quando o proprietário retornou com o sorvete, o jovem pediu o vidro de picles para si. $O$ proprietário colocou o sundae e o vidro de picles em uma caixa e disse que o total seria de três reais. Ojovem foi pegar sua carteira e descobriu que a havia esquecido no trabalho. Tudo o que tinha era um real e cinquenta centavos trocados. O proprietário olhou para o sorvete, então para o picles, e sorriu. Disse ao jovem que um real e cinquenta eram suficientes.

\section{Example 2}

Question 7 - Reasoning

7. Tell the patient, "I'm going to repeat some sayings that have meaning beyond words. After I say each phrase, I want you to explain to me what people mean when they use that phrase." After reading each idiom, ask, "What do people mean when they say that?" Allow a maximum of 30 seconds for the patient to respond to each idiom, and present all three idioms before going on the next item. Record the responses. For each idiom, score 2 points for an accurate interpretation of the figurative meaning. Score 1 point for a partially correct response that contains at least 1 figurative meaning that indicates that the patient has a general understanding of the idiom. Score 0 for an incorrect or concrete response.

\section{a. Raining cats and dogs}

b. Bite your tongue

c. Hard-nosed

The sayings of the original questionnaire were common to speakers of the language source of the questionnaire, but unknown in Brazilian culture. Thus, they have been replaced by sayings presented below.

7. Diga ao paciente, "Agora, vou repetir algumas expressões que têm significado além das palavras. Após a leitura de cada frase, eu quero que você me explique o que as pessoas querem dizer quando usam essa frase." Após ler cada frase, pergunte, "O que as pessoas querem dizer quando falam isso?". Permita um tempo de 30 segundos para que o paciente responda cada frase, e apresente as três frases antes de prosseguir para o próximo item. Anote as respostas. Para cada frase, conte dois pontos para uma interpretação exata do significado figurativo. Conte um ponto para uma resposta parcialmente correta que contenha, pelo menos, um significado figurativo que indique que o paciente compreendeu a frase. Conte zero para uma resposta incorreta ou inespecífica.

\section{a. Chover no molhado}

b. Morder a língua

\section{c. Cara-de-pau}

These questions were modified in accordance with suggestions from the tested subjects and the expert committee. At this stage, there was a consensus to adapt these other items from the test (Chart 2):

Statistically significant differences were found in the total score (on account of organization, memory and reasoning) due to different educational level, which proved to be higher among those with higher socioeconomic status $(\mathrm{p}<0.001)$.

The sample of individuals who have not suffered TBI in the study of Dr. Adamovich and Dr. Henderson was 78 people. Of these, 36 were female and 38 male (of which 4 individuals the gender was not reported). The youngest participant was 15 years old and the oldest 88 years old. ${ }^{13}$ In our study, as shown above, 38 were female and 17 were male and the age of the respondents ranged from 18-81 years.

Chart 2. Items which required cultural adaptation.

\begin{tabular}{lc}
\hline Ability & Items \\
\hline Orientation & $2 b, 2 e, 2 f$ \\
Organization & 6 \\
Recall & $2 b, 2 h, 2 g, 9$ \\
Reasoning & $3 a, 3 b, 4 e, 7,8,11$ \\
\hline
\end{tabular}


Table 5. Means of total and partial scores in the SCATBI-Original sample and SCATBI-Portuguese.

\begin{tabular}{lcccccc}
\hline & \multicolumn{3}{c}{ SCATBI-Original } & \multicolumn{3}{c}{ SCATBI-Portuguese } \\
\cline { 2 - 7 } & $\mathrm{N}$ & Mean & SD & $\mathrm{N}$ & Mean & SD \\
\hline Total Score & 78 & 193.7 & 12.0 & 55 & 198.3 & 12.0 \\
Perception and & 78 & 55.7 & 3.9 & 55 & 57.2 & 1.2 \\
Discrimination & & & & & & \\
Orientation & 78 & 19.8 & 0.7 & 55 & 19.9 & 1.6 \\
Organization & 78 & 26.3 & 2.5 & 55 & 29.2 & 2.18 \\
Memory/Recall & 78 & 44.7 & 6.4 & 55 & 44.0 & 5.3 \\
Reasoning & 78 & 47.2 & 7.9 & 55 & 47.9 & 5.5 \\
\hline
\end{tabular}

SD: standard deviation.

The average of the scores obtained in the validation sample with healthy controls in the USA and Canada is presented below (Table 5) ${ }^{13}$. The mean scores of the original sample by Adamovich and Henderson are slightly lower than the average scores found in the Brazilian population. Fifty-four percent of the Brazilian respondents had college degrees, while $61.8 \%$ of the healthy controls from the original sample had $>13$ years of schooling.

The goal of this study was limited to the translation and adaptation of SCATBI. Cross-cultural adaptation tries to ensure a consistency in the content and face validity between source and target versions of a questionnaire. It should therefore follow that the resultant version has sound reliability and validity if the original version did. It is highly recommended that, after the translation and adaptation process, the investigators ensure that the new version has demonstrated the measurement properties needed for the intended application. The new instrument should retain both the item-level characteristics such as item-to-scale correlations and internal consistency; and the score-level characteristics of reliability, construct validity, and responsiveness ${ }^{16}$. It was possible to work some of these tests of reliability and validity into the pretesting process (stage 5 of the adaptation), which demonstrated an internal consistency of the Brazilian version equivalent to the original version of SCATBI and also its domains were positively and significantly correlated to the total score, although larger sample sizes are advisable for further studies on consistency and validity and this is a limitation of this present study.

The SCATBI is a comprehensive cognitive-linguistic battery, assessing individuals in an extensive age range. Its Brazilian version will be of fundamental importance to clinicians and Neuropsychology researchers, as a useful tool for the diagnosis and monitoring of cognitive impairments after a TBI in Brazil.

This translated and culturally adapted version of SCATBI to the Brazilian culture and the Portuguese language was adequate, being able to discriminate the performance of different age groups, socioeconomic status and educational level. Our sample results showed that this Brazilian version is equivalent to the American's and it may be used in the study of the Brazilian population.

\section{Acknowledgements}

The authors are grateful to Dr. Brenda B. Adamovich and Dr. Jennifer Henderson, Ph.D. (Copyright @ 1992 PRO-ED) who gave their permission for this study.

\section{References}

1. Melo TRJ, Olivieira Filho J, Silva AR, Moreira Júnior ED. ]

Prognostic factors about morbidity and lethality in head injury]. Arq Neuropsiquiatria. 2005;63(4):1054-7. Portuguese. doi:10.1590/S0004-282X2005000600026

2. Hyder AA, Wunderlich CA, Puvanachandra P, Gururaj G, Kobusingye OC. The impact of traumatic brain injuries: a global perspective. NeuroRehabilitation. 2007;22(5):341-53.

3. Diaz AP, Schwarzbold ML, Thais ME, Hohl A, Bertotti MM, Schmoeller $R$ et al. Psychiatric disorders and health-related quality of life after severe traumatic brain injury: a prospective study. J Neurotrauma. 2012;29(6):1029-37. doi:10.1089/neu.2011.2089

4. Martins ET, Linhares MN, Sousa DS, Schroeder HK, Meinerz J, Rigo LA et al. Mortality in severe traumatic brain injury: a multivariated analysis of 748 Brazilian patients from Florianópolis City. J Trauma. 2009;67(1):85-90. doi:10.1097/TA.0b013e318187acee

5. Thais MEO, Cavallazzi G, Formolo DA, Castro LD, Schmoeller R, Guarnieri $R$ et al. Limited predictive power of hospitalization variables for long-term cognitive prognosis in adult patients with severe traumatic brain injury.J Neuropsychol. 2014;8(1):125-39. doi:10.1111/jnp.12000

6. Diaz AP, Schwarzbold ML, Thais MEO, Cavallazzi GG, Schmoeller R, Nunes JC et al. Personality changes and return to work after severe traumatic brain injury: a prospective study. Rev Bras Psiquiatr. 2014;36(3):213-9. doi:10.1590/1516-4446-2013-1303
7. Zappalà G. The frontal lobes: executive and behavioural control of human reasoning. Implications for understanding brain injury. Riv Neurobiol. 2008;54:195-202.

8. Gouveia PAR, Fabrício AM. Avaliação neuropsicológica em traumatismo cranioencefálico. In: Andrade VM, Santos FH, Bueno OFA, editors. Neuropsicologia hoje. São Paulo: Artes Médicas; 2004. p. 297-305.

9. Ministério da Saúde (BR), Secretaria de Atenção à Saúde, Departamento de Ações Programáticas Estratégicas. Diretrizes de atenção à reabilitação da pessoa com traumatismo cranioencefálico. Brasília, DF: Ministério da Saúde; 2013.

10. Zafonte RD, Hammond FM, Mann NR, Wood DL, Black KL, Millis SR. Relationship between Glasgow coma scale and functional outcome. Am J Phys Med. Rehabil. 1996;75(5):364-69. doi:10.1097/00002060-199609000-00012

11. McDonald S, Pearce S. Requests that overcome listener reluctance: impairment associated with executive dysfunction in brain injury. Brain Lang. 1998;61(1):88-104. doi:10.1006/brln.1997.1846

12. Duff MC, Proctor A, Haley K. Mild traumatic brain injury (MTBI): assessment and treatment procedures used by speech-language pathologists (SLPS). Brain Inj. 2002; 16(9):773-87. doi:10.1080/02699050210128870 
13. Adamovich BLB, Hutchinson TA. Differential performance of traumatic brain injury subjects and non-brain-injured peers on cognitive tasks. In: 22 nd Clinical Aphasiology Conference: Clinical Aphasiology Conference; 1992; Durango, CO. Durango: Pro-Ed; 1994. p. 257-64.

14. World Medical Association. World Medical Association Declaration of Helsinki: ethical principles for medical research involving human subjects. JAMA. 2013;310(20):2191-4. doi:10.1001/jama.2013.281053

15. Guillemin F, Bombardier C, Beaton D. Cross-cultural adaptation of health-related quality of life measures: literature review and proposed guidelines. J Clin Epidemiol. 1993;46(12):1417-32. doi:10.1016/0895-4356(93)90142-N

16. Beaton DE, Bombardier C, Guillemin F, Ferraz MB. Guidelines for the process of cross-cultural adaptation of self-report measures. Spine. 2000;25(24):3186-91. doi:10.1097/00007632-200012150-00014

17. Associação Brasileira de Empresas de Pesquisa - ABEP. Critério de classificação econômica Brasil 2012. São Paulo: Associação
Brasileira de Empresas de Pesquisa; 2013 [cited 2014 June 15]. Available from: http://www.abep.org/criterio-brasil

18. Anderson RT, Aaronson N, Wilkin D. Critical review of the international assessments of health-related quality of life generic instruments. In: Shuaker S, Berzon R. The International Assessment of Health-Related Quality of Life: theory, translation, measurement and analysis. Oxford, UK: Rapid Communication of Oxford;1995. p. 11-37.

19. Bullinger $M$, Alonso J, Apolone G, Leplège A, Sullivan M, Wood-Dauphinee $S$ et al. Translating health status questionnaires and evaluating their quality: the IQOLA Project approach. International Quality of Life Assessment. J Clin Epidemiol. 1998;51(11):913-23. doi:10.1016/S0895-4356(98)00082-1

20. González-Calvo J, González VM, Lorig K. Cultural diversity issues in the development of valid and reliable measures of health status. Arthritis Care Res. 1997;10(6):448-56. doi:10.1002/art.1790100613

21. Malkmus D, Booth B, Kodimer G. Rehabilitation of the head-injured adult: comprehensive management. Downey, CA: Professional Staff Association of Ranchos Los Amigos Hospital; 1980. 